Т. К. Кормухина (доц. АУДПО «Приморский краевой институт развития образования", г. Владивосток)

\title{
РАЗГОВОРНАЯ РЕЧЬ ИЛИ СПЕЦИАЛЬНАЯ ЛЕКСИКА: ПРИОРИТЕТЫ НА ЗАНЯТИЯХ РКИ
}

Статья посвящена проблеме обучения иностранных студентов навыкам разговорной речи. Выявляется тенденция на коммуникативаность в современных учебных пособиях по РКИ. Предлагается вариант адаптации текста в соответствии с практикой разговорной речи.

Ключевые слова: русская разговорная речь, учебные пособия, реальный дискурс.

Ни методисты, ни практикующие преподаватели РКИ не сомневаются в том, что студент-иностранец, обучающийся в чужой языковой среде, нуждается в навыках понимания и владения повседневной русской речью, в сформированной коммуникативной компетенции, позволяющей адекватно реагировать в различных ситуациях общения. Занятия РКИ вполне удовлетворяют эту потребность обучающегося. Однако перед преподавателем стоит и другая не менее важная задача подготовить студента к будущему обучению по специальности на русском языке. Для этого необходимо помочь студенту освоить лексику по будущей специальности [об опыте обучения профессиональной лексике см.: Говорухина, Монгина 2019]. Обе задачи важны и неизбежно ставят преподавателя перед выбором приоритета.

Современные учебники по русскому языку для иностранцев коммуникативно ориентированы. По сравнению с советскими учебниками, в которых собственно разговорный материал практически не представлен, с учебниками конца XX века, в которых появляются задания, содержащие конструкции разговорной речи (например, пособие Н.И. Молчановской «Современная русская разговорная речь» [Молчановская 1992], 
В.В. Красных «Вопрос? Вопрос...» [Красных 2000].), современные учебники предлагают более разнообразные и системные задания. Так, в издании «Русская разговорная речь для иностранцев: продвинутый этап обучения» (М.М. Одесская, Р.А. Харитонова) отрабатываются различные варианты лексики со значением оценки характера человека, реакции на его поведение, согласие или отказ выполнить просьбу, вводятся эмоционально окрашенные модели высказываний, разговорные грамматические формы [Одесская, Харитонова 1999]. Н.Б. Караванова - автор пособий «Слушаем живую русскую речь» [Караванова 2009], изучая которое англоговорящие студенты слушают реальную русскую речь в разнообразии интонационных конструкций, в формате диалогов и монологов; «Говорите правильно! Курс разговорной речи» [Караванова 2008]. Эта позитивная, на наш взгляд, методическая тенденция «от грамматики к коммуникации», позволяет освоить студентам азы естественной коммуникации, почувствовать специфику живого русского языка, приблизиться к решению проблемы коммуникации в полиэтнической образовательной среде, когда использование ситуации говорения на русском языке может стать фактором «надгруппового единства, снимающего конфликты» [Говорухина 2018б): 520]. Названные пособия, однако, адресованы студентам продвинутого уровня, совершенствующих полученные навыки владения русским языком. Однако и для начального этапа обучения языку появляются пособия, в которых все больше проявляется коммуникативный аспект. Так, можно назвать учебник «Владимир. Золотое кольцо» (Г.М. Лёвина, Е.Н. Николенко), включающий диалоги, в основе которых структуры реальной разговорной речи [Левина, Николаенко 2011].

Важность погружения студентов в стихию живого разговорного языка осознают методисты и практики преподавания РКИ именно сегодня, ведь еще в XX веке задача подготовки обучающихся к рецепции спонтанной речи не рассматривалась как актуальная. Так, В.А. Степаненко в статье «Современное состояние русского языка в аспекте обучения русскому языку как иностранному» отмечает, что «не ориентируясь в том речевом потоке, который звучит с экранов телевизора, радио, в речи лекторов, наш учащийся беспомощен в языковой среде. Разрыв между учебной и естественной 
коммуникацией существовал всегда, но никогда не был так значим, как сегодня» [Степаненко 2008: 12]. На сегодняшний день несмотря на образовавшуюся тенденцию на коммуникативность в разработке новейших учебников РКИ, в методике преподавания проблема обучения русской разговорной речи не изучена в полной мере. Скорее, как значимые исключения можно назвать работу Е.А. Земской «Русская разговорная речь: лингвистический анализ и проблемы обучения» [Земская 2006], в которой предлагается анализ разговорной речи (описываются ее уровни, вербальные и невербальные средства, приводятся этикетные речевые формулы). Автор квалифицирует русскую разговорную речь как некодифицированную, но нормированную. Важным представляется сформировать у студентов не только представление о конкретных разговорных фразах и лексике, но о в целом об особенностях этой сферы речи. Назовем еще работу О.Б. Сиротининой «Русская разговорная речь» [Сиротинина 1983], в которой поуровнево описываются фонетические, морфологические, лексические, синтаксические особенности русской разговорной речи.

Ситуативность разговорного языка не хаотичная, но предполагает существование более или менее устойчивых стереотипных механизмов речепорождения. Этим механизмам и стоит обучить студентов. Это, во-первых, формулы вопросаответа, просьбы, обусловленные той или иной сферой общения человека, формулы этикета. Как справедливо замечает Е.А. Земская, «важно учитывать ту шкалу правильности, которая характеризует нормы разговорной речи, т. е. следует учить не только официально-книжным конструкциям <..>, но и лаконичным построениям, реально бытующим в жизни» [Земская 2006: 15]. Важно, чтобы иностранные студенты понимали разные диапазоны звучащей речи, овладели в той или иной степени не только лексикой, но и реальному словоупотреблению в разных коммуникативных ситуациях.

Недостаточно ввести слово «конечно», «хорошо» как ответ на просьбу о помощи. Ведь в реальной речевой практике иностранцы могут услышать и такие варианты: «само собой», «легко» и др.

Преподавателям РКИ известно, что лучше всего в разговорной лексике разбираются студенты, у которых 
появляются русские друзья. Общаясь в неофициальной речевой обстановке, они усваивают лексику, которая так отличается от учебной.

В ситуации, когда базовые учебники по РКИ предлагают отредактированный, олитературенный, нормированный вариант живого общения, необходимо привлекать другие источники: телевизионные программы (новостные, репортажные), фильмы, песни, видео и аудиозаписи в блогах. Слушая песни, учащиеся начинают воспроизводить их, цитировать. Включение названных источников стимулирует спонтанную речь.

Нередко диалоги, воспроизводящие живую разговорную речь в учебниках, воспринимаются как искусственные. Например:

- Олег, какие у тебя планы на завтра?

- Утром я буду заниматься, а вечером я хочу пойти в кино. Я буду смотреть новый фильм.

Повторение местоимения «я» не характерно для разговорной речи, которая стремится к емкости.

Еще один пример:

- Что вы будете делать летом?

- Сначала мы будем сдавать экзамены, а потом мы будем отдыхать на море.

В этом случае вообще можно было бы избежать местоимений в ответе, чтобы максимально приблизить его к реальности:

- Олег, какие у тебя планы на завтра?

- Утром буду заниматься, а вечером хочу пойти в кино. Буду смотреть новый фильм.

Приведем пример «искусственного» диалога и предлагаемый вариант его адаптации с учетом специфики разговорной речи. Оригинал:

- Иван, где ты был вчера вечером? Я приходил к тебе два раза, но тебя не было дома.

- Мы с Димой были в театре на встрече с актерами.

- А почему вы не пригласили меня?

- Извини, пожалуйста, но мы тебя вчера не видели и не могли пригласить. Знаешь, Иван, в субботу в театре будет интересный спектакль. Хочешь пойти с нами?

- С удовольствием. А кто там будет выступать? 
- Московские артисты: и очень известные, и совсем молодые.

- Обязательно пойду с вами. А где и когда мы встретимся?

- Давай встретимся с тобой в 7 часов на станичи метро «Автово».

- Договорились. Буду ждать тебя Диму ровно в 7 часов на станции метро «Автово» у входа.

- До встречи.

Отредактированный вариант:

- Привет, Иван, ты где был вчера вечером? Я приходил два раза, но тебя не было дома.

- Да мы с Димой были в театре на встрече с актерами.

- Нормально. А почему меня не пригласили?

- Извини, пожалуйста, нө мы тебя вчера не видели и не могли пригласить. Знаешь что, Иван, в субботу в тееатре будет интересный спектакль. Хочешь пойти с нами?

- Само собой. А кто ғам будет выступать?

- Московские артисты: и очень известные, и совсем молодые.

- Обязательно пойду е вамғ. А где и когда мы встретимся?

- Давай-ветретимея с төбөй в 7 часов у метро «Автово».

- Договорились. Буду ждать вас ровно в 7 часов $y$ метро «Автово», у входа.

- До встречи.

В ходе редактуры был изменен порядок слов, введены разговорные частицы, неофициальные лексемы согласия, исключены избыточные лексемы, повторы.

Итак, проблема обучения студентов-иностранцев современной русской разговорной речи остается сегодня актуальной. Несмотря на то, что новейшие дидактические материалы демонстрируют позитивную динамику в ориентации на разговорную речь, все еще нередко воспроизводимые диалоги воспринимаются как искусственно созданные. Автору современного учебника необходимо понимать специфику разговорной речи, обладать умением адаптировать учебные материалы путем введения вариантов реального словоупотребления с целью «формирования у учащихся адаптивности и особой компетенции - способности к 
продуктивному поликультурному диалогу» [Говорухина 2018 а): 119].

\section{ЛИТЕРАТУРА}

1. Говорухина Ю.А, Монгина Ф.М. Профессиональная лексика в учебном пособии по русскому языку как иностранному: из опыта обучения иностранных военнослужаших//Русистика, 2019,№ 1.-С. $29-41$.

2. Говорухина Ю.А. Особенности коммуникации в поликультурной образовательной среде вуза // Педагогическая деятельность как творческий процесс: материалы всероссийской научно-практической конференции с международным участием. -Махачкала, 2018. - С. 118-126.

3. Говорухина Ю.А. Педагогическое сопровождение смешанных национальных групा, изучающих русский язык как иностранный // Актуальные проблемы совершенствования высшего образования: материалы XIII научно-методической конференции с международным участием. - Ярославль, 2018.С. 519-521.

4. Земская Е.А. Русская разговорная речь: лингвистический анализи проблемы обучения.-М., 2006.-239с.

5. Караванова Н.Б. Слушаем живую русскую речь. - М., 2009.- 116 с.

6. Караванова Н.Б. Говоритеправильно! = Survival russian: курс русской разговорной речи [дпя говорящих наанглийском языке]. - М., 2015. - 311 с.

7. Красных В.В. Вопрос? Вопрос...-М., 2000.-53 с.

8. Л Лёвина Г.М., НиколенкоЕ. Ю. Золотоекольцо.-М., СПб., 2011.- 152 с.

9. Молчановская Н.И. Современная русская разговорная речь. Тексты и упражнения.-М., 1992.- 96 с.

10. Одесская М.М., Харитонова Р.А. Русская разговорная речь для иностранцев: продвинупый этап обучения.-М., 1999. - 90с.

11. Сиротинина О.Б.Русская разговорная речь. - М, $1983 .-80$ c.

12. Степаненко В.А. Современнюе состояние русского языка в аспекте обучения русскому языку как иностранному // Проблемы преподавания русского языка как иностранного: новыетенденции обучения. - М., 2008.-С. 6-12.

(С) Кормухина Т.К., 2021 г. 